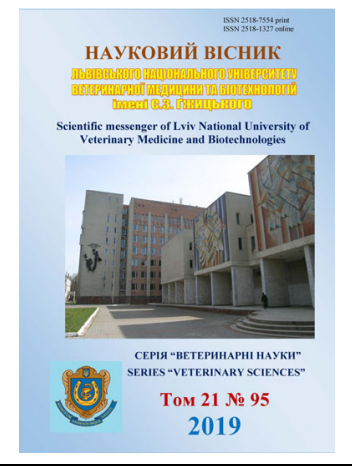

\author{
Науковий вісник Дьвівського національного університету \\ ветеринарної медицини та біотехнологій імені С.3. Гжицького. \\ Серія: Ветеринарні науки
}
Scientific Messenger of Lviv National University of Veterinary Medicine and Biotechnologies. Series: Veterinary sciences

\title{
Avaluation of morphofunctional condition of rats organism for study of toxicity of the preparation tilmicosine basis
}

\author{
M.I. Zhyla ${ }^{1}$, I.P. Patereha ${ }^{1}$, E. Tomaszewska ${ }^{2}$, S. Muszynski ${ }^{2}$, P. Dobrowolski ${ }^{3}$, O.M. Dubin ${ }^{4}$, Y.B. Koval ${ }^{5}$ \\ ${ }^{1}$ State Scientific-Research Control Institute of Veterinary Medicinal Products and Feed Additives, Lviv, Ukraine \\ ${ }^{2}$ University of Life Sciences in Lublin, Lublin, Poland \\ ${ }^{3}$ Maria Curie-Sklodowska University, Lublin, Poland \\ ${ }^{4}$ PSC "Technolog”, Uman, Ukraine \\ ${ }^{5}$ Ivan Franko National University of Lviv, Lviv, Ukraine
}

Article info

Received 05.09.2019

Received in revised form 07.10.2019

Accepted 08.10.2019

State Scientific-Research Control Institute of Veterinary Medicinal Products and Feed Additives Donetska Str., 11, Lviv, 79019, Ukraine.

Tel.:+38-067-706-96-11

E-mail:zhyla-m@ukr.net

University of Life Sciences in Lublin, Akademicka 13, 20-950, Lublin, Poland.

Maria Curie-Sklodowska University, Plac Marii Curie-Sktodowskiej 5 20-031 Lublin, Poland.

PSC "Technolog", Stara prorizna Str. 8 Uman, 20300, Ukraine.

Ivan Franko National University of Lviv, Universytetska Str., 1, Lviv, 79000, Ukraine.
Zhyla, M.I., Patereha, I.P., Tomaszewska, E., Muszynski, S., Dobrowolski, P., Dubin, O.M., \& Koval, Y.B. (2019). Avaluation of morphofunctional condition of rats organism for study of toxicity of the preparation tilmicosine basis. Scientific Messenger of Lviv National University of Veterinary Medicine and Biotechnologies. Series: Veterinary sciences, 21(95), 47-54. doi: 10.32718/nvlvet9509

The article presents the study results of the acute and subacute toxicity of the veterinary drug "Tylmozyn 25" (solution for oral administration) based on tilmicosin. Intra-gastric administration of "Tylmozyn 25" to white mice at a dose of $25000 \mathrm{mg} / \mathrm{kg}$ of body weight caused the death of $100 \%$ of the animals, a dose of $15000 \mathrm{mg} / \mathrm{kg}$ of body weight caused the death of $66 \%$ of the white mice. The average time of death was 2 and 5 hours correspondingly. While determining the toxicity of "Tylmozyn 25" in white rats, we did not spot the death of any studied animal at any administered dose $(5000,15000,25000 \mathrm{mg} / \mathrm{kg}$ of body weight). Based on the result of our study, we conclude that the veterinary drug Tylmozyn 25 belongs to the fourth of toxicity class - low toxic substances. LD50 of Tylmozyn 25 in white mice is $14167 \mathrm{mg} / \mathrm{kg}$, while in white rats $L D_{50}$ is higher than $25000 \mathrm{mg} / \mathrm{kg}$. Testing on white rats intra-gastric drug "Tylmozyn 25 " during for 14 days, both in therapeutic $(80 \mathrm{mg} / \mathrm{kg}$ of body weight) and 10-fold doses ( $800 \mathrm{mg} / \mathrm{kg}$ of body weight) did not cause animal death, but caused a decrease in body weight, a significant decrease in the coefficients of weight of the liver and spleen and a tendency to increase the coefficients of weight of the heart and lungs compared with the animals of the control group. Animals which got the drug at a dose of $800 \mathrm{mg} / \mathrm{kg}$ of body weight showed erythrocytosis, leukopenia, increased enzymatic activity of AST, ALT, and $\mathrm{LDH}$, the content of total protein against to decrease urea and creatinine, which may indicate impaired liver, kidney function and hematopoietic organs. The macroscopic and microscopic structure of the internal organs of the experimental rats is preserved. Rats receiving a tenfold therapeutic dose of the drug for 14 days, histologically revealed the most granular protein dystrophy in the liver and kidneys, which was manifested by discomplexation of the lamellae, presence of hepatocytes with uneven granular cytoplasm, slightly colored cytoplasm, hypertrophied nuclei, renal convoluted tubules and narrowing of their lumen, compaction of the mesh of the renal corpuscle. In the myocardium, the branching, swelling of the muscle fibers, swelling of the stroma with cell infiltrates, mainly of the lympho-histiocytic series, was observed, which indicated the development of serosa myocarditis. Structural changes in the liver, kidneys and heart were confirmed by biochemical parameters of the enzymatic activity of the serum of rats of this group.

Key words: rats, mice, toxicity, preclinical tests, hematological, biochemical, pathomorphological studies, internal organs, "Tylmozyn 25 ".

\section{Оцінка морфофункціонального стану організму щурів за вивчення токсичності препарату на основі тилмікозину}

М.I. Жила ${ }^{1}$, І.П. Патерега ${ }^{1}$, Е. Томашевска², С. Мушиньскі ${ }^{2}$, П. Добровольскі ${ }^{3}$, О.М. Дубін ${ }^{4}$ Ю.Б. Коваль ${ }^{5}$ 
'Державний науково-дослідний контрольний інститут ветеринарних препаратів та кормових добавок, м. Львів, Україна

${ }^{2}$ Люблінський природничий університет, м. Люблін, Польща

${ }^{3}$ Університет Марії Кюрі-Складовської, м. Люблін, Польщза

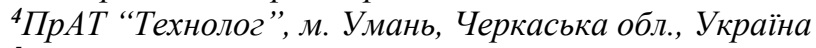

5 Львівський національний університет імені Івана Франка, м. Львів, Украӥна

У статті наведені результати вивчення гострої та підгострої токсичності препарату “Тилмозин 25” (розчин для перорального застосування), виготовленого на основі тилмікозину. Внутрішньошлункове введення препарату “Тилмозин 25 ” білим мишам, у дозі 25000 мг/кг маси тіла викликало 100\% загибель тварин, доза 15000 мг/кг - 66\% загибелі тварин. Середній час загибелі становив 2 та 5 годин відповідно. При визначенні гострої токсичності препарату “Тилмозин 25” на білих шурах загибелі тварин не виявляли за введення жодної з доз (5000, 15000, 25000 мг/кг маси тіла). У результаті проведених досліджень було встановлено, щзо препарат “Тилмозин 25” належить до 4-го класу токсичності - малотоксичні речовини. ЛД5о при його внутрішньошлунковому введенні білим мишам становить 14167 мг/кг, а для білих щурів є більшою за 25000 мг/кг. Застосування білим щурам внутрішньошлунково препарату “Тилмозин 25” впродовж 14 діб як у терапевтичній (80 мг/кг маси тіла), так $і$ 10-кратній дозах (800 мг/кг маси тіла) не викликало загибелі тварин, проте спричиняло зменшення маси тіла, достовірне зниження коефіцієнтів маси печінки та селезінки і тенденцію до збільшення коефіцієнтів маси серця і легень порівняно з тваринами контрольної групи. У тварин, які отримували досліджуваний препарат в дозі 800 мг/кг маси тіла, встановлено еритроцитоз, лейкопенію, підвищення активності АлАТ, АсАТ, ЛДГ, вмісту загального білка на фоні зниження вмісту сечовини та креатиніну, шо може вказувати на порушення функиї печінки, нирок та органів кровотворення. Макроскопічна та мікроскопічна структура внутрішніх органів досліджуваних груп шурів збережена. У щурів, які отримували 10-кратну терапевтичну дозу препарату впродовж 14 діб, гістологічно виявляли вогнища зернистої білкової дистрофії в печінці та нирках, щчо проявлялося дискомплексацією пластинчатої будови печінкових часточок, наявність гепатоцитів з неоднорідною, зернистою, слабо забарвленою цитоплазмою та гіпертрофованими ядрами, набуханням епітелію звивистих ниркових канальців та звуженням їхнього просвіту, ущільненням сітки ниркових клубочків. У міокарді спостерігали розволокнення, набухання м'язових волокон, набряк строми з клітинними інфільтратами переважно лімфогістіоцитарного ряду, щзо вказувало на розвиток серозного міокардиту. Встановлені структурні зміни у печінці, нирках, сериі були підтверджені біохімічними показниками ферментативної активності сироватки крові шурів даної групи.

Ключові слова: щури, миші, токсичність, доклінічні випробування, гематологічні, біохімічні, патоморфологічні дослідження, внутрішні органи, “Тилмозин 25.”

\section{Вступ}

Упродовж багатьох років основною складовою при лікуванні захворювань запального характеру в органах дихання, травлення у тварин є протимікробна терапія. При виборі антибактеріального засобу важливим є його спектр антимікробної дії та рівень чутливості до нього збудника чи збудників захворювання. Тилмікозин належить до групи макролідів, який у малих концентраціях діє бактеріостатично, а у великих - бактерицидно на грампозитивні та грамнегативні мікроорганізми, а саме на Pasteurella spp., Haemophilus spp., Actinomyces spp., Corynebacterium spp., Staphylococcus aureus, Clostridium perfringens, a також (Mycoplasma spp.). Тоді, як Enterobacter aerogenes, Escherichia coli, Klebsiella pneumoniae, Pseudomonas aeruginosa, Salmonella i Serratia spp., вважаються стійкими до тилмікозину (Ose, 1987; Prescott \& Baggot, 1993; Ziv et al., 1995; Plumb, 2005; Hunter, 2007).

Однією з обов'язкових вимог при реєстрації ветеринарних препаратів $\epsilon$ наявність результатів доклінічних та клінічних випробувань з вивчення токсичності, розподілу, метаболізму та виведення із організму діючої субстанції, а також терапевтичного ефекту, побічних реакцій. Встановлення параметрів токсичності лікарського засобу є першочерговою складовою у проведенні доклінічних досліджень на лабораторних тваринах. Важливою складовою у процесі доклінічного випробування ветеринарних препаратів $\epsilon$ проведення лабораторних досліджень. За допомогою гематологічних, біохімічних, патоморфологічних, імунологічних та інших методів проводиться вивчен- ня біологічної реакції організму тварин на дію ветеринарних лікарських засобів, що дозволяє скласти точне уявлення про характер і важкість перебігу патологічного процесу за дії досліджуваних речовин. Патоморфологічні методи дослідження істотно доповнюють картину загальної інтоксикації, характер і ступінь вираженості порушень у різних органах, тканинах та $€$ обов'язковими в гострому і хронічному токсикологічному експерименті (Kosenko et al., 1997; Litvinova et al., 2001; Kotsiumbas et al., 2006; Zhyla et al., 2016; Gutyj et al., 2018; Todoriuk et al., 2018; Patereha et al., 2019).

Метою нашої роботи було встановити параметри токсичності препарату “Тилмозин 25” (розчин для перорального застосування), виготовленого на основі тилмікозину.

\section{Матеріал і методи досліджень}

Вивчення токсичності препарату “Тилмозин 25" передбачало встановлення параметрів гострої та підгострої токсичності. Гостру токсичність встановлювали на білих мишах масою 19-22 г та білих щурах масою 180-200 г за внутрішньошлункового одноразового введення. При вивченні гострої токсичності на білих мишах в орієнтовному досліді препарат вводили в дозах 5000 мг/кг, 15000 мг/кг 25000 мг/кг маси тіла, що відповідало 0,1 мл, 0,3 мл та 0,5 мл препарату на тварину. Було встановлено, що препарат, введений у дозах 15000 та 25000 мг/кг маси тіла, викликав загибель тварин. Тому в розгорнутому досліді препарат вводили в діапазоні доз 5000, 10000, 15000, 20000 та 25000 мг/кг маси тіла. При вивченні гострої токсич- 
ності на білих щурах в орієнтовному досліді препарат вводили в дозах 5000 мг/кг, 15000 мг/кг та 25000 мг/кг маси тіла, що відповідало 1,0 мл, 3,0 мл та 5,0 мл препарату на тварину. Дозу 25000 мг/кг маси тіла тварини було введено повторно на подвійній кількості тварин. Всього в експериментах було використано 56 лабораторних тварин (білих мишей - 42 та білих щурів - 12 голів). ЛД 50 препарату визначали за методом Г. Кербера (Kosenko et al., 1997; Kotsiumbas et al., 2006).

Підгостру токсичність препарату “Тилмозин 25" вивчали на білих щурах масою тіла 180-200 г. Для проведення досліду було сформовано за принципом аналогів дві дослідні та контрольну групи, по 6 тварин в кожній. Досліджуваний препарат вводили внутрішньошлунково щоденно упродовж 14 діб. Тваринам контрольної групи застосовували воду. Тваринам 1 дослідної групи препарат вводили у терапевтичній дозі (одноразова) - 80 мг/кг маси тіла, тваринам 2 групи - в десятикратній терапевтичній дозі: 800 мг/кг маси тіла.

Упродовж усього періоду експерименту вели спостереження за лабораторними тваринами. На наступну добу, після закінчення введення препарату, за умов легкого ефірного наркозу тварин декапітували та відбирали кров для гематологічних, біохімічних досліджень. Проводили повний патологоанатомічний розтин, визначали коефіцієнти маси внутрішніх органів, відбирали зразки органів (печінка, нирки, кишечник, тимус, селезінка) для гістологічного дослідження (Litvinova et al., 2001; Kotsiumbas et al., 2006).

Для гематологічних досліджень використовували кров стабілізовану ЕДТА, а для біохімічних досліджень - сироватку крові. В стабілізованій крові визначали: вміст гемоглобіну, кількість еритроцитів, гематокрит, кількість лейкоцитів - за допомогою гематологічного аналізатора Mythic-18. У сироватці крові визначали: загальний білок за допомогою рефрактометра ІРФ-22, активність ензимів (АлАТ, АсАТ, ЛДГ), вміст креатиніну, сечовини за допомогою напівавтоматичного біохімічного аналізатора HumaLyzer 3000 з використанням стандартних наборів фірми Human (Kotsiumbas et al., 2006; 2016).

Матеріал для гістологічного дослідження (шматочки внутрішніх органів і тканин) фіксували в 10\% нейтральному розчині формаліну з подальшою заливкою в парафін. Гістозрізи виготовляли на санному мікротомі МС-2. Для дослідження загальної морфологічної структури органів і тканин та гістозрізи фарбували гематоксиліном та еозином. Мікроскопію проводили $з$ допомогою мікроскопа OLIMPUS CX-41 i морфометричної програми DP-SOFT (Merkulov, 1969; Kotsiumbas et al., 2006).

Отримані результати обробляли статистично із визначенням середніх величин, достовірного інтервалу при наявному рівні значущості $\mathrm{P}<0,05$ з урахуванням поправки на множинні порівняння, нормальності та гомогенності дисперсії, критерію Стьюдента. Для побудови діаграм розкиду використовували пакет Matplotlib (Kotsiumbas et al., 2006; Hunter, 2007).

\section{Результати та їх обговорення}

При визначенні гострої токсичності препарату “Тилмозин 25” було встановлено, що його застосування білим мишам у дозі 25000 мг/кг викликало 100\% загибель тварин, у дозі 15000 мг/кг - 66\% загибелі тварин. Середній час загибелі становив 2 та 5 годин відповідно. При визначенні гострої токсичності препарату “Тилмозин 25" на білих щурах загибелі тварин не виявляли за введення жодної 3 доз (5000, 15000, 25000 мг/кг маси тіла).

Отже, препарат “Тилмозин 25” (розчин для перорального застосування) згідно зі СОУ 85.2-37736:2011 належить до малотоксичних речовин 4 клас. ЛД 50 при його внутрішньошлунковому введенні білим мишам (обчислення за методом Г. Кербера) становить 14167 мг/кг, а для білих щурів $\epsilon$ більшою за 25000 мг/кг.

Наступним етапом роботи було вивчення впливу препарату на організм тварин за довготривалого застосування (14 діб). При застосуванні препарату впродовж усього періоду експерименту не було виявлено загибелі лабораторних тварин. Поряд з тим, варто зазначити, що тварини були активними, добре поїдали корм, шерсть була густою, блискучою. Проте маса тіла у щурів дослідних груп була достовірно ( $\mathrm{P}<0,01)$ меншою порівняно $з$ контролем у 1 групі на 19,2\%, 2 групі - на 24,5\%. Так, маса тіла щурів на період завершення експерименту становила:в 1 групі $200,0 \pm 2,9$ г; у 2 групі - 187,0 \pm 6,2 г; контроль $247,5 \pm 7,0$ г.

При вивченні впливу досліджуваного препарату на гематологічні показники у щурів встановлено, що застосування препарату впродовж 14 діб у терапевтичній та 10-кратній терапевтичній дозах не спричинювало суттєвих змін у концентрації гемоглобіну та величини гематокриту. Порівняно 3 контрольною групою кількість еритроцитів мала тенденцію до збільшення у щурів 1 та 2 дослідних груп, поряд 3 тим відмічали зменшення кількості лейкоцитів в обох дослідних групах щурів, проте достовірною $(\mathrm{P}<0,01)$ різниця показників була у щурів 2 дослідної групи (рис. 1).

Як видно з даних, наведених на рисунку 2, при вивченні впливу препарату на біохімічні показники сироватки крові у тварин 1 та 2 дослідних груп, порівнянно 3 контролем спостерігали тенденцію до підвищення активності АлАТ, вмісту загального білка та достовірне $(\mathrm{P}<0,05)$ збільшення активності АсАТ, ЛДГ на фоні достовірного (Р < 0,05) зниження вмісту сечовини та креатиніну, що вказувало на порушення функціонального стану печінки, нирок, м'язової тканини. 

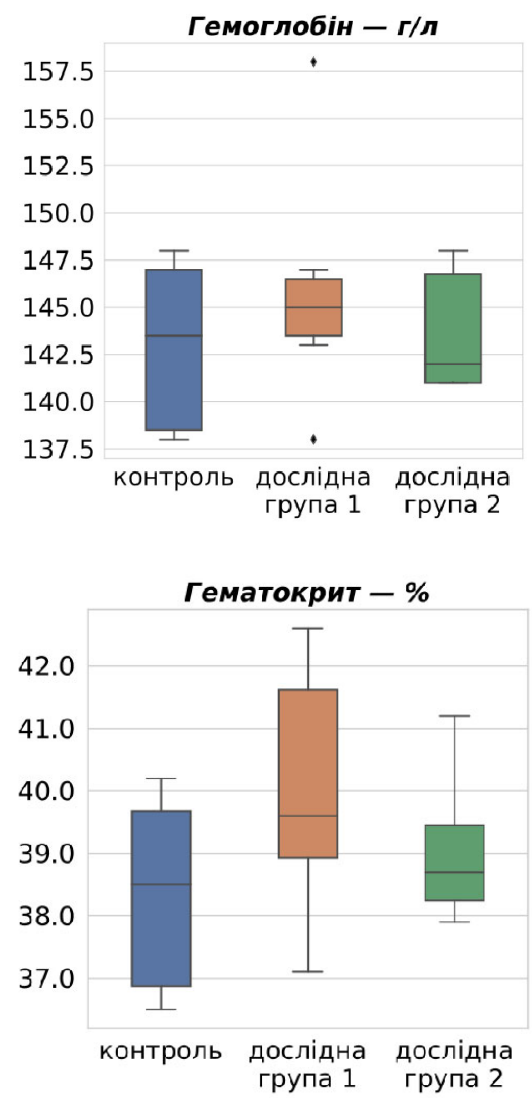
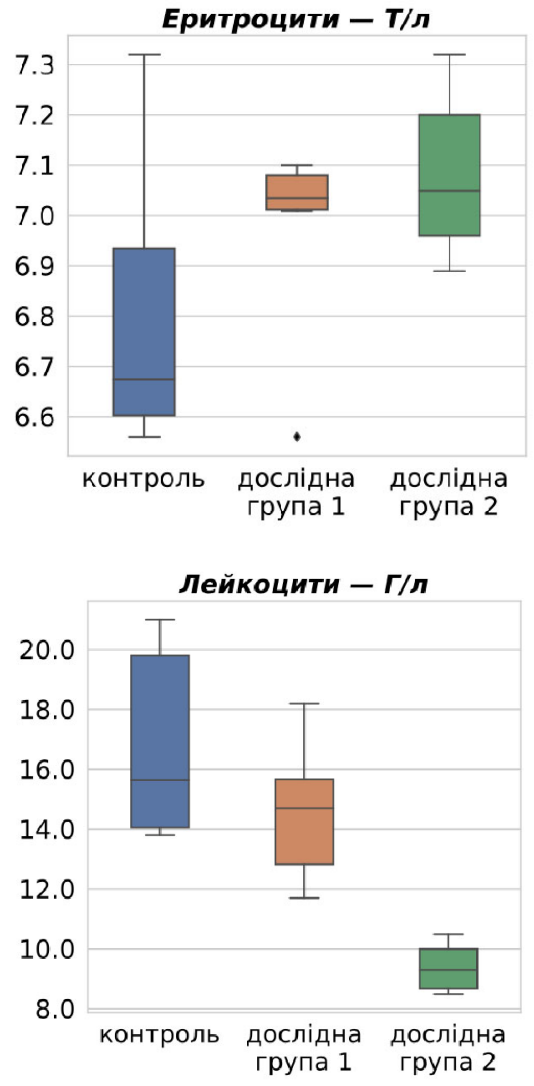

Рис. 1. Діаграма розкиду гематологічних показників білих щурів на 14-ту добу досліду за вивчення підгострої токсичності препарату “Тилмозин 25 ”

Внутрішньошлункове застосування препарату “Тилмозин 25” білим щурам впродовж 14 діб як у терапевтичній так і 10-кратній терапевтичній дозах викликало достовірне зниження коефіцієнтів маси печінки та селезінки і тенденцію до збільшення коефіцієнтів маси серця і легень порівняно з тваринами контрольної групи. Показники коефіцієнтів маси нирок не суттєво відрізнялися від контролю.

При патологоанатомічному розтині та макроскопічній оцінці у щурів контрольної та 1 дослідної груп не виявляли видимих змін у внутрішніх органах, слизових i серозних покривах. Розміщення внутрішніх органів анатомічно правильне, очеревина та костальна плевра гладка, блискуча, волога, без нашарувань.

У щурів 2 дослідної групи спостерігали в окремих випадках зміну забарвлення печінки, а саме вогнища світло-коричневого кольору, вялої консистенції. Нирки бобовидної форми, темно-червоного кольору, краї розрізу сходяться, границя між кірковою і мозковою зонами збережена, капсула знімається легко. Селезінка темно-вишневого кольору, краї гострі, на розрізі структура збережена, лінія розрізу сходиться, зіскребок незначний. Підшлункова залоза часточкової будови, пружної консистенції, світло-рожевого кольору.

Гістологічна структура печінки щурів збережена. У більшості щурів, які отримували 10-кратну терапевтичну дозу препарату Тилмозин 25 впродовж 14 діб виявляли дискомплексацію пластинчатої будови часточок, гепатоцити 3 неоднорідною, зернистою, слабо забарвленою цитоплазмою, дрібними поодинокими вакуольними включеннями та гіпертрофованими ядрами, що вказувало на розвиток вогнищевої білкової дистрофії (рис. 3-5).

Міокард щурів контрольної та 1 дослідної групи представлений пучками м'язових волокон зі збереженою поперечною посмугованістю та ексцентрично розміщеними ядрами кардіоміоцитів. У міокарді щурів 2 дослідної групи спостерігали розволокнення, набухання м'язових волокон, набряк строми 3 клітинними інфільтратами переважно лімфо-гістіоцитарного ряду, що вказувало на розвиток дистрофічних процесів та запальної реакції (рис. 6-7). 

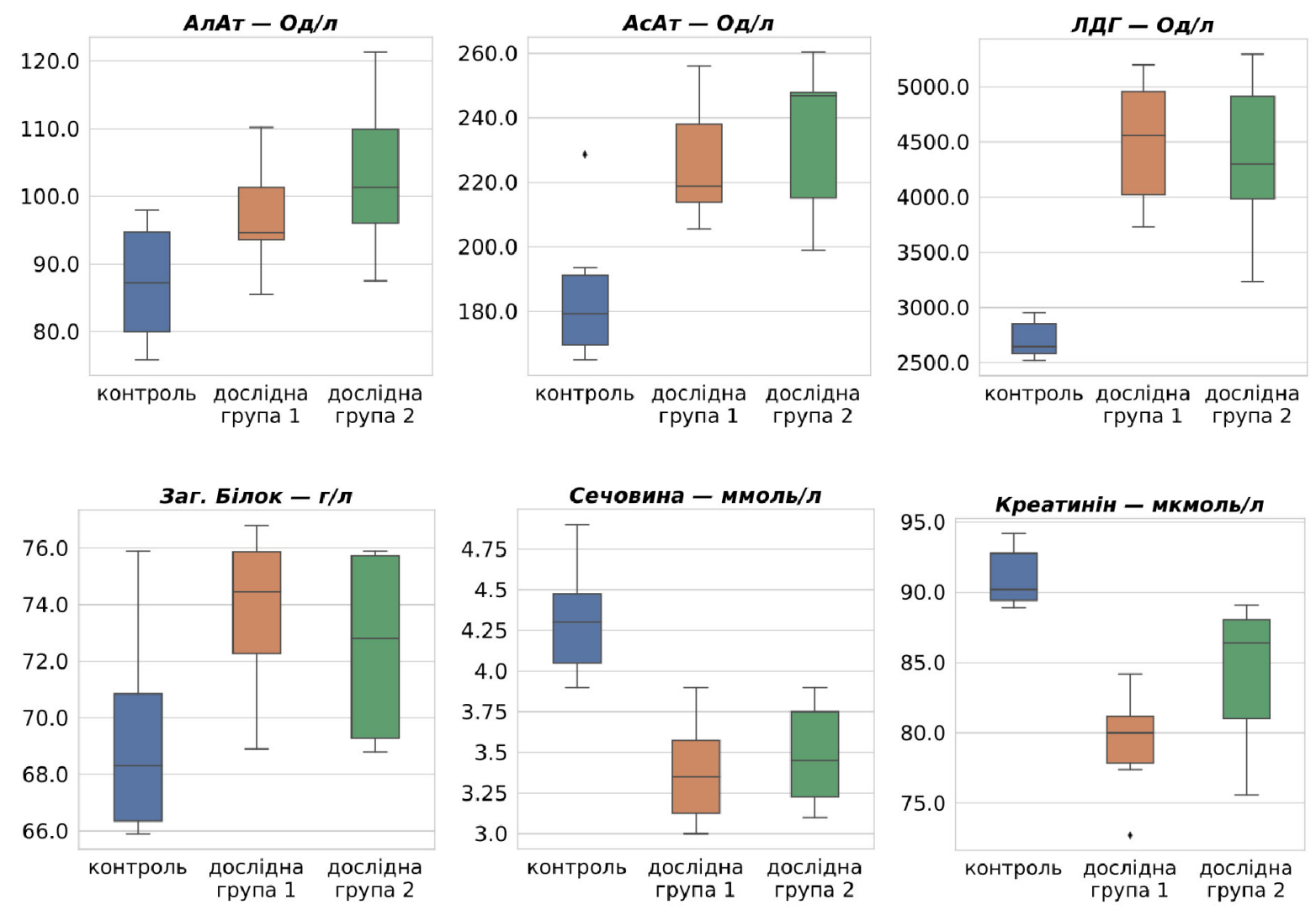

Pис. 2. Діаграма розкиду біохімічних показників крові білих щурів на 14-ту добу досліду за вивчення підгострої токсичності препарату “Тилмозин 25 ”

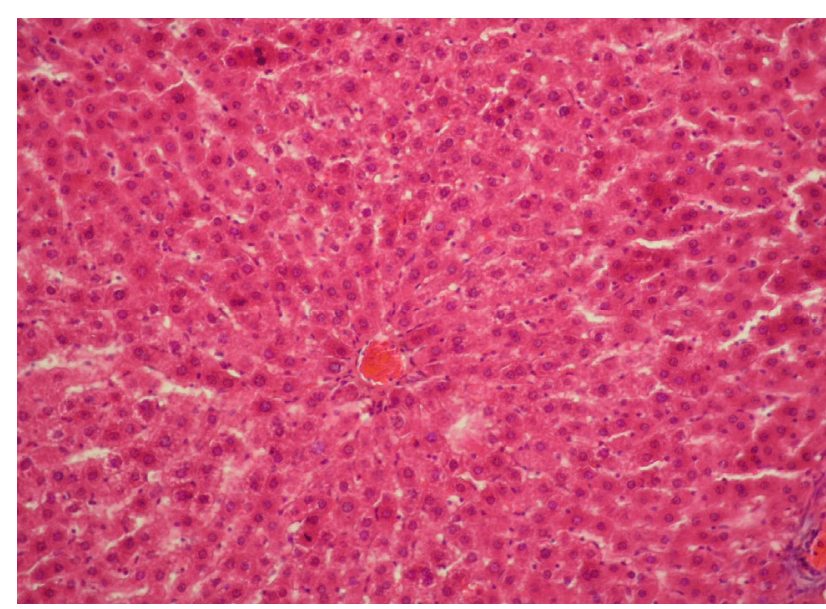

Рис. 3. Печінка щура контрольної групи. 14 доба.

Пластинчата структура часточки збережена, ядра гепатоцитів чітко контуровані, цитоплазма однорідна, добре зафарбована. Гематоксилін та еозин.

Ок. 10 , об. 20

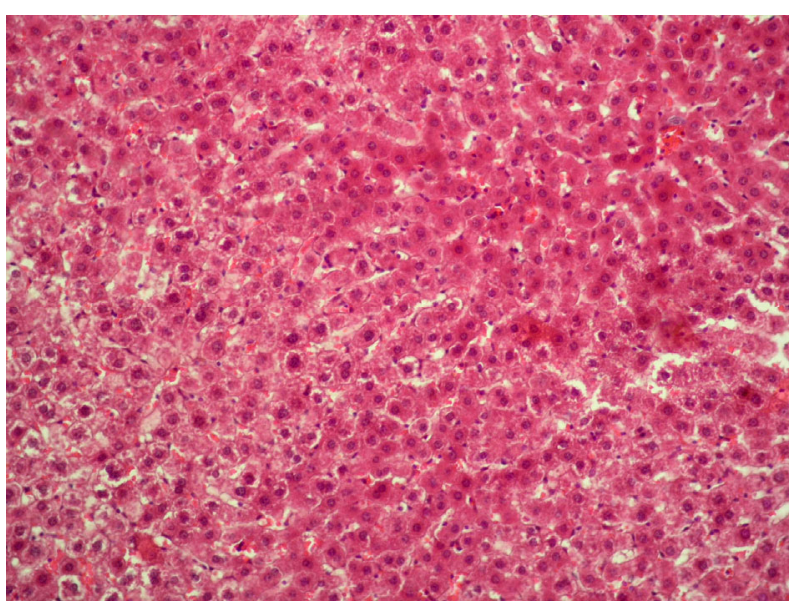

Рис. 4. Вогнищева дистрофія гепатоцитів у печінковій часточці щура 2 дослідної групи. Гематоксилін та еозин. Ок. 10, об. 20 


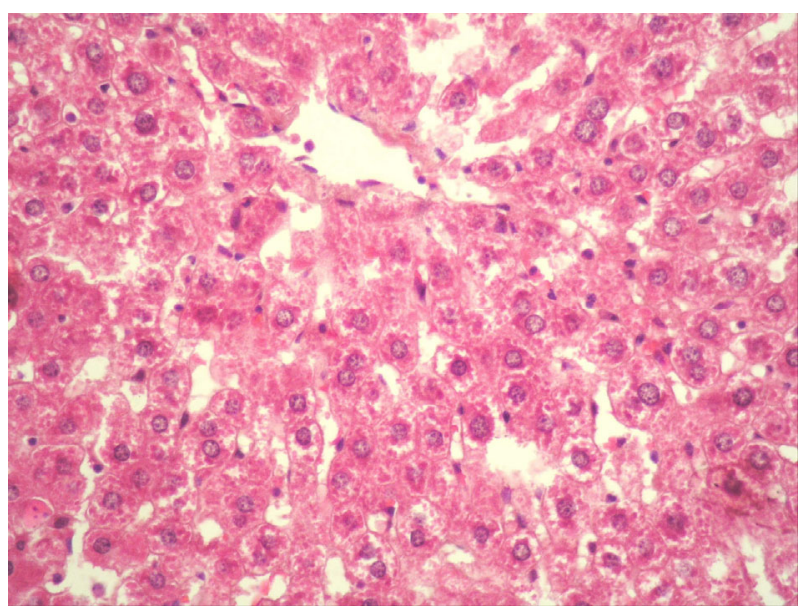

Рис. 5. Печінка щура 2 дослідної групи на 14 добу. Цитоплазма гепатоцитів зерниста, ядра слабо зафарбовані, гіпертрофовані. Гематоксилін та еозин. Ок. 10 , об. 40

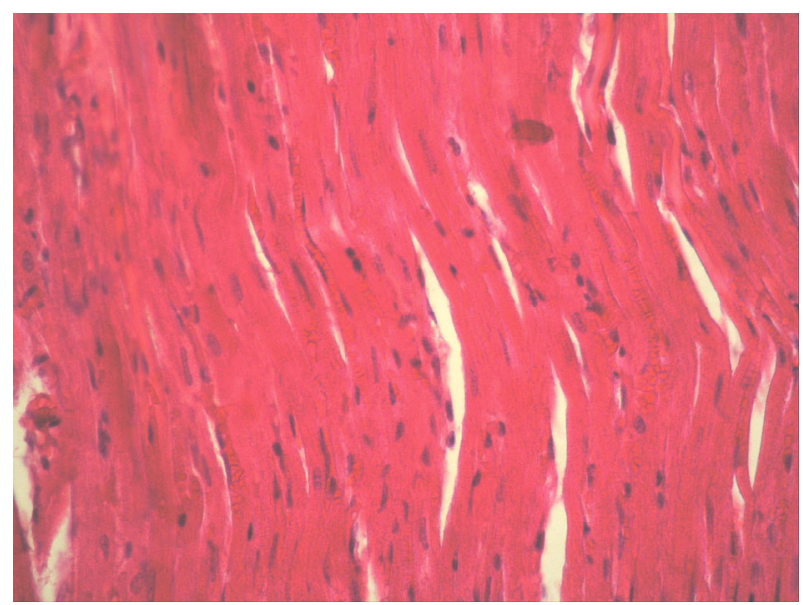

Рис. 6. Міокард щура контрольної групи на 14 добу. Кардіоміоцити збережені, ядра ексцентрично розміщені. Гематоксилін та еозин. Ок. 10, об. 20

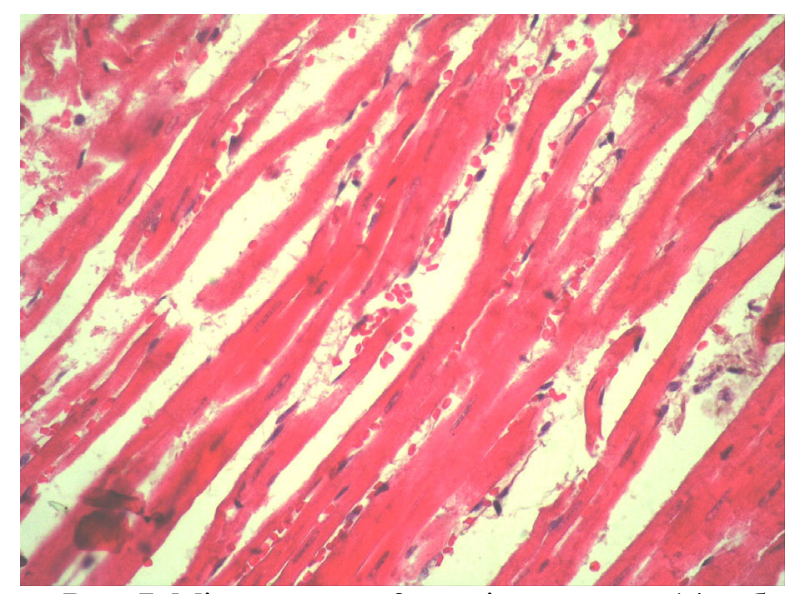

Рис. 7. Міокард щура 2 дослідної групи. 14 доба. Розволокнення і набухання м'язових волокон, строма набрякла $з$ клітинними інфільтратами. Гематоксилін та еозин. Ок. 10, об. 20

У гістологічній структурі нирок щурів, яким застосовували 10 -кратну терапевтичну дозу препарату
“Тилмозин 25” впродовж 14 діб, виявляли вогнищеву білкову дистрофію епітелію звивистих ниркових канальців з набуханням епітелію, звуженням просвіту. Капілярна сітка ниркових клубочків ущільнена, капсула Шумлянського-Боумена розтягнута, без вмісту (рис. 8-9).

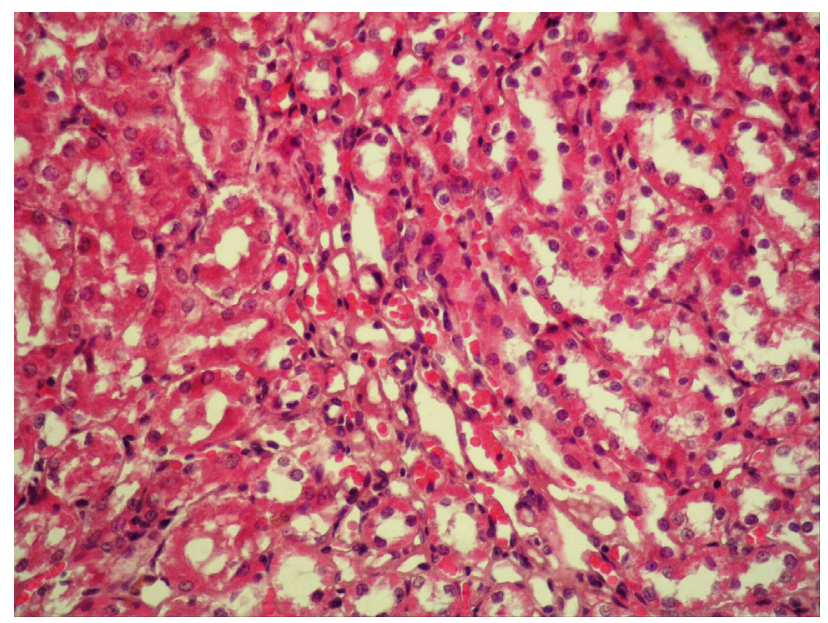

Рис. 8. Нирка щура 2 дослідної групи на 14 добу. Вогнища дистрофічного ураження ниркових канальців. Гематоксилін та еозин. Ок. 10, об. 20

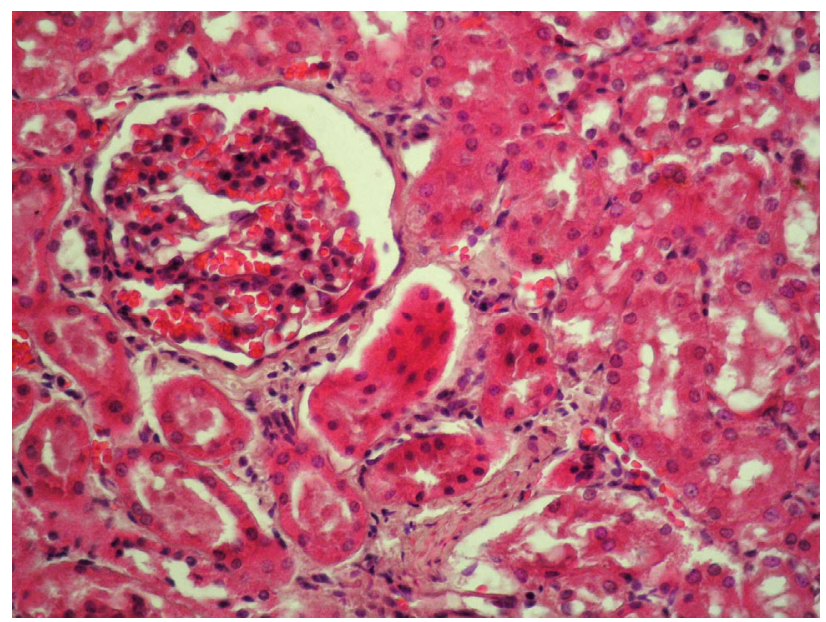

Рис. 9. Нирка щура 2 дослідної групи на 14 добу. Ниркові клубочки ущільнені, просвіт між капсулою розширений. Гематоксилін та еозин. Ок. 10, об. 40

Гістологічна структура селезінки збережена у всіх досліджуваних групах тварин. Поділ на червону та білу пульпу збережений. Червона пульпа помірно кровонаповнена, біла пульпа представлена переважно первинними лімфоїдними (лімфатичними) вузликами округлої форми. Вузлики щільно заселені клітинами лімфоїдного ряду, реактивні центри траплялися рідко (рис. 10-11).

Суттєвої відмінності між контрольною та дослідними групами у гістоструктурі органів шлунковокишкового тракту, легень не виявляли. 


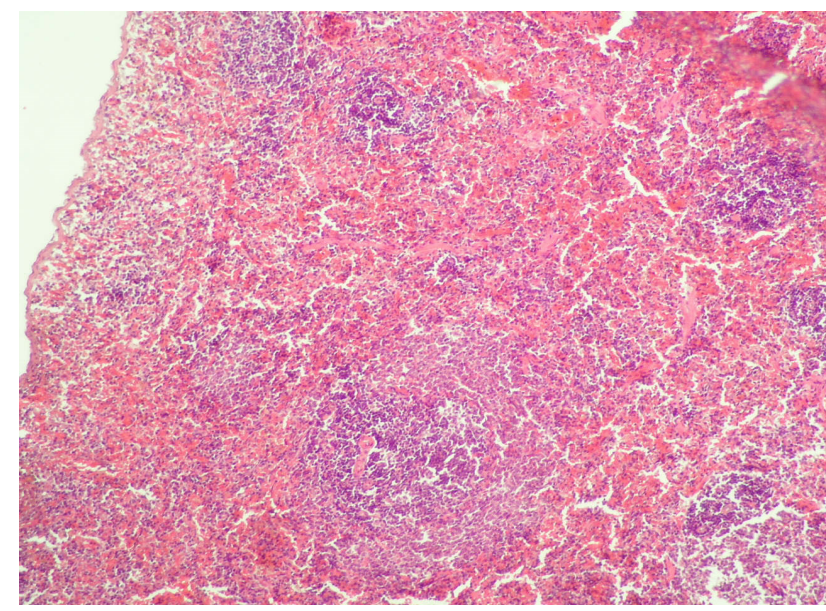

Рис. 10. Гістоструктура селезінки щура 2 дослідної групи на 14 добу. Поділ на червону і білу пульпу збережений. Гематоксилін та еозин. Ок. 10, об. 10

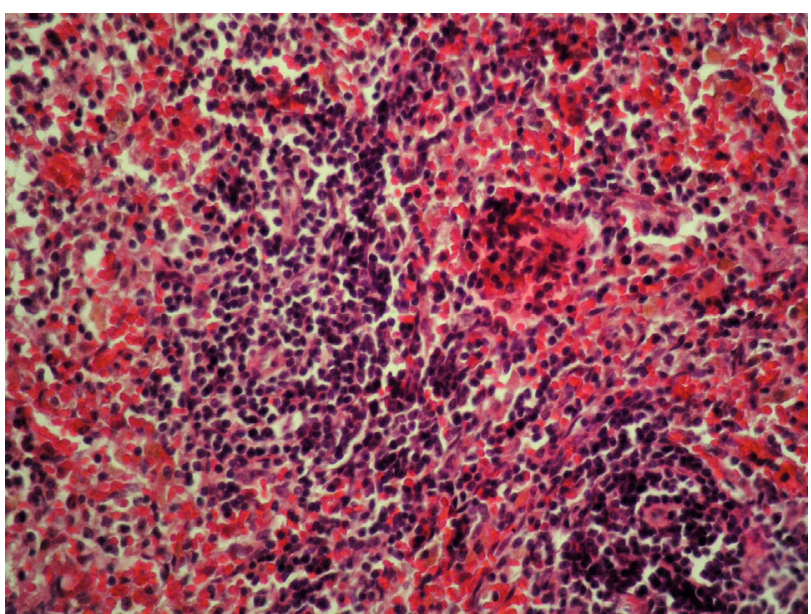

Рис. 11. Щільно заселений клітинами лімфатичний вузлик селезінки щура 2 дослідної групи на 14 добу. Гематоксилін та еозин. Ок. 10, об. 20

Отже, макроскопічна та мікроскопічна структура досліджуваних внутрішніх органів щурів за вивчення підгострої токсичності препарату “Тилмозин 25” збережена. У більшості щурів, які отримували 10-кратну терапевтичну дозу препарату впродовж 14 діб, гістологічно встановлено вогнищеву білкову дистрофію печінки, нирок, міокарда, серозний міокардит, що мають переважно зворотний характер.

\section{Висновки}

Препарат “Тилмозин 25” належить до 4-го класу токсичності, тобто до малотоксичних речовин. ЛД при його внутрішньошлунковому введенні білим мишам становить 14167 мг/кг, а для білих щурів $\epsilon$ більшою за 25000 мг/кг маси тіла.

Застосування білим щурам внутрішньошлунково препарату “Тилмозин 25” впродовж 14 діб як у терапевтичні дозі (80 мг/кг маси тіла), так і 10-кратній (800 мг/кг маси тіла) не викликало загибелі тварин, проте спричиняло зменшення маси тіла, достовірне зниження коефіцієнтів маси печінки та селезінки і тенденцію до збільшення коефіцієнтів маси серця i легень порівняно $з$ тваринами контрольної групи.

У білих щурів, які отримували досліджуваний препарат в дозі 800 мг/кг маси тіла, встановлено еритроцитоз, лейкопенію, підвищення активності АлАТ, AcАТ, ЛДГ, вмісту загального білка на фоні зниження вмісту сечовини та креатиніну. Макроскопічна та мікроскопічна структура внутрішніх органів досліджуваних груп щурів збережена. У більшості щурів, які отримували 10-кратну терапевтичну дозу препарату впродовж 14 діб, гістологічно встановлено вогнищеву білкову дистрофію печінки, нирок, серозний міокард.

Перспективи подальших досліджень. Результати досліджень будуть використані для контролю якості препарату за показниками безпечності.

\section{References}

Adams, H.R. (2001). Veterinary Pharmacology and Therapeutics, 8th ed. Ames: Iowa State University Press, 876-882.

Gutyj, B., Grymak, Y., Hunchak, V., Mysak, A., Nazaruk, N., Brezvyn, O., Hariv, I., Shcherbatyy, A., Semeniv, B., Bushueva, I., Parchenko, V., \& Kaplaushenko, A. (2018). Preclinical searches of the preparation Thireomagnile. Ukrainian Journal of Ecology, 8(1), 688-695. doi: 10.15421/2018 267.

Hunter, J.D. (2007). Matplotlib: A 2D Graphics Environment, Computing in Science \& Engineering, 9(3), 90-95. doi: 10.1109/MCSE.2007.55.

Kosenko, M.V., Malyk, O.H., Kotsiumbas, I.Ya., Patereha, I.P., \& Chura, D.O. (1997). Toksykolohichnyi kontrol novykh zasobiv zakhystu tvaryn: Metodychni rekomendatsii. K (in Ukrainian).

Kotsiumbas, I.Ya., Malyk, O.H., \& Patereha, I.P. (2006). Doklinichni doslidzhennia veterynarnykh likarskykh zasobiv. Lviv: Triada plius (in Ukrainian).

Kotsiumbas, I.Ya., Zhyla, M.I., \& Shkodiak, N.V. (2016). Morfolohichni ta biokhimichni pokaznyky krovi laboratornykh tvaryn: Metodychni rekomendatsii. Lviv (in Ukrainian).

Litvinova, N.V., Filonenko-Patrusheva, M.A., Frantsuzova, S.B., \& Khrapak, V.V. (2001). Doklinichni doslidzhennia likarskykh zasobiv: Metodychni rekomendatsii. K.: Avitsenna (in Ukrainian).

Merkulov, G.A. (1969). Kurs patologogistologicheskoj tehniki. L.: Medicina (in Russian).

Ose, E.E. (1987). In vitro antibacterial properties of EL-870, a new semisynthetic macrolide antibiotic. J Antibiot,40(2), 190-194. doi: 10.7164/antibiotics.40.190.

Patereha, I.P., Kushnir, V.I., Zhyla, M.I., \& Dubin, O.M. (2019). Acute and subacute toxicity of the drug based on tylosin tartrate. Scientific Messenger of Lviv National University of Veterinary Medicine and Biotechnologies. Series: Veterinary sciences, 21(94), 97-102. doi: 10.32718/nvlvet9418.

Plumb, D.C. (2005). Veterinary drug handbook. Stockholm, Wisconsin: PharmaVet Inc. 
Prescott, J.F., \& Baggot, J.D. (1993). Antimicrobial therapy in veterinary medicine. 2nd ed. Ames, IA: Iowa State University Press, 119-126; 187-203.

Todoriuk, V.B., Hunchak, V.M., Gutyj, B.V., Gufriy, D.F., Hariv, I.I., Khomyk, R.I. , \& Vasiv, R.O. (2018). Preclinical research of the experimental preparation "Ferosel T". Ukrainian Journal of Veterinary and Agricultural Sciences, 1(1), 3-9. doi: 10.32718/ujvas1-1.01.

Zhyla, M.I., Piatnychko, O.M., \& Shkodiak, N.V. (2016).
Kontrol yakosti henerychnykh veterynarnykh likarskykh zasobiv. Naukovyi visnyk Lvivskoho natsionalnoho universytetu veterynarnoi medytsyny ta biotekhnolohii imeni S.Z. Hzhytskoho, 18, 1(65), 3541 (in Ukrainian).

Ziv, G., Shem-Tov, M., Glickman, A. et al. (1995). Tilmicosin antibacterial activity and pharmacokinetics in cows. J Vet Pharmacol Ther, 18(5), 340-345. doi: 10.1111/j.1365-2885.1995.tb00601.x. 